\title{
Genetic polymorphisms in DNA base excision repair gene XRCCI and the risk of squamous cell carcinoma of the head and neck Michal Kowalski1 ${ }^{1}$ Karolina Przybylowska1 ${ }^{1}$, Pawel Rusin ${ }^{2}$, Jurek Olszewski Alina Morawiec-Sztandera ${ }^{4}$, Anna Bielecka-Kowalska1, Wioletta Pietruszewska ${ }^{5}$, Wojciech Mlynarski ${ }^{6}$, Szemraj Janusz ${ }^{7}$ and Ireneusz Majsterek*1,2
}

Address: ${ }^{1}$ Department of Chronopharmacology, Medical University of Lodz, Lodz, Poland, ${ }^{2}$ Department of Molecular Genetics, University of Lodz, Lodz, Poland, ${ }^{3}$ Department of Otolaryngology and Oncology, Medical University of Lodz, Lodz, Poland, ${ }^{4}$ Department of Head and Neck Cancer, Medical University of Lodz, Lodz, Poland, ${ }^{5}$ Department of Otolaryngology, Medical University of Lodz, Lodz, Poland, ${ }^{6}$ Department of Pediatrics, Medical University of Lodz, Lodz, Poland and ${ }^{7}$ Department of Medical Biochemistry, Medical University of Lodz, Lodz, Poland

Email: Michal Kowalski - zabiakow@o2.pl; Karolina Przybylowska - tonina1@wp.pl; Pawel Rusin - pawelrusin@gmail.com;

Jurek Olszewski - jolsz@imp.lodz.pl; Alina Morawiec-Sztandera - morawiec@csk.am.lodz.pl; Anna Bielecka-Kowalska - zabiakow@o2.pl; Wioletta Pietruszewska - pietruszewska@op.pl; Wojciech Mlynarski - Wojciech.Mlynarski@joslin.harvard.edu; Szemraj

Janusz - jszemraj@csk.am.lodz.pl; Ireneusz Majsterek* - imajst@biol.uni.lodz.pl

* Corresponding author

Published: 13 March 2009

Journal of Experimental \& Clinical Cancer Research 2009, 28:37 doi:10.1 186/I756-9966-28-37

This article is available from: http://www.jeccr.com/content/28/l/37

(c) 2009 Kowalski et al; licensee BioMed Central Ltd.

This is an Open Access article distributed under the terms of the Creative Commons Attribution License (http://creativecommons.org/licenses/by/2.0), which permits unrestricted use, distribution, and reproduction in any medium, provided the original work is properly cited.

\begin{abstract}
Background: The genes of base excision repair (BER) pathway have been extensively studied in the association with various human cancers. We performed a case-control study to test the association between two common single nucleotide polymorphisms (SNPs) of XRCCI gene with human head and neck squamous cell carcinoma (HNSCC).
\end{abstract}

Methods: The genotype analysis of Arg194Trp and Arg399Gln gene polymorphisms for 92 HNSCC patients and 124 controls of cancer free subjects, in Polish population were performed using the PCR-based restriction fragment length polymorphism (PCR-RFLP) with endonuclease Mspl.

Results: No altered risk has been found individually for these SNPs, however haplotypes analysis showed high association with head and neck cancer. The highest frequency, according to wild-type of Arg 194Arg and Arg399Arg genotypes, was identified for Arg 194Trp-Arg399Arg haplotype (OR, 2.96; $95 \% \mathrm{Cl}, \mathrm{I} .0 \mathrm{I}-8.80$ ).

Conclusion: Finally, we identified the combined Arg 194Trp-Arg399Arg genotype of base excision repair gene $\mathrm{XRCCl}$ that was associated with HNSCC and may have an impact on identification of a high-risk cancer population.

\section{Background}

Genome integrity is maintained by an intricate network of DNA repair proteins $[1,2]$. Organisms have developed several DNA repair pathways as well as DNA damage checkpoints. Although each pathway is addressed individually, the cross talk exists between repair pathways, and 
there are instances in which a DNA-repair protein is involved in more than one pathway. Single nucleotide polymorphisms (SNPs) in DNA repair genes may be associated with differences in the repair efficiency of DNA damage and may influence an individual's risk of cancer. Establishing this connection, however, has been a challenge due to the complexity of interactions that affect the repair pathways $[3,4]$. Increasing evidence links environmental exposures, subtle modification in DNA repair efficiency, and cancer risk [5].

The genes belonging to base excision repair (BER) pathway, such as X-ray Repair Cross Complementing Group 1 (XRCC1) have been extensively studied in the association with various human cancer [6-14]. Two major SNPs of the XRCC1 gene have been identified at codon 194 (C > T substitution at position 26304, exon 6, Arg to Trp) and 399 ( $G$ > A substitution at position 28152, exon 10, Arg to Gln). The XRCC1 Arg399Gln polymorphism is located in the area coding for a PARP binding site. PARP is a zincfnger containing enzyme that detects DNA strand breaks [15]. Carriers of the XRCC1 399 Gln variant allele have been shown to have higher levels of DNA adducts [16] and to be at greater risk for ionizing radiation sensitivity [17] and tobacco correlated DNA damage [18-20].

The XRCC1 protein plays an important role in the maintenance of genomic stability through the both base excision and single-strand break repair by acting as a scaffold for other DNA repair proteins, such as DNA glycosylases, polymerase beta [21] and ligase III [22]. XRCC1 participates in the first step of BER by interacting with the numerous of human DNA glycosylases including hOGG1, MPG, hNTH1 and NEIL1 [23,24]. It was found that XRCC1, through its NTD and BRCT1 domains, has affinity to form a covalent complex via Schiff base with AP sites. It was also reported that XRCC1 affinity was higher when the DNA carried an AP-lyase- or APE1-incised AP site [25]. This results in an acceleration of the overall repair process of abasic site, which can be used as a substrate by DNA polymerase beta. Thus, this suggests mechanism by which XRCC1, through its multiple proteinprotein interactions plays essential role in the resealing of the repaired DNA strand.

Head and neck squamous cell carcinoma (HNSCC) comprise about $6 \%$ of all malignant neoplasm. Overall survival is low especially in developing countries and the major risk factors of HNSCC became smoking or alcohol consumption [26]. Although the functional significance of XRCC1 polymorphism has not yet been fully elucidated, due to smoking and alcohol consumption attitude it may increase risk of head and neck cancer occurrence [27]. To test this hypothesis, we performed a hospital based case-control study using a polymerase chain reac- tion-restriction fragment length polymorphism (PCRRFLP) assay to genotype two polymorphisms of DNA repair gene XRCC1 Arg194Trp and Arg399Gln in relation to head and neck cancer susceptibility.

\section{Methods \\ Patients}

Blood samples were obtained from 92 patients (50 men and 42 women, mean age $48.7 \pm 11.13$ ) with squamous carcinoma of head and neck. Control samples consisted of age matched 124 cancer-free blood donors (63 men and 61 women, mean age $44.47 \pm 19.24$ ). Despite of 4 years younger controls then patients, there were not statistical differences in age of analyzed groups $(P=0.169)$. Prior to examination, the patients and control subjects, did not receive medicaments like antibiotics or steroids. Patients enrolled to the examination were analyzed according to cancer staging system of the TNM Classification of Malignant Tumours that describes the extent of cancer in a patient's body: $T$ describes the size of the tumor and whether it has invaded nearby tissue, $\mathrm{N}$ describes regional lymph nodes that are involved and $M$ describes distant metastasis (spread of cancer from one body part to another). Within the control group selected subjects (52 cases) were classified as smokers for at least 10 years, up to 10 cigarettes per day. The smoking attitude of head and neck cancer group was also analyzed for nonsmoking patients, patients smoking 10 cigarettes per day for ten years, patients smoking 20 cigarettes per day for twenty years and patients smoking 20 cigarettes per day for thirty years. All patients and controls subjects were recruited from three medical units of Head and Neck Neoplasm Surgery Departments, Medical University of Lodz, Poland. All subjects included into the study were unrelated Caucasians and inhibited Lodz district, Poland. The study was approved by the Local Ethic Committee and written consent was obtained from each patient or healthy blood donor before enrolling into the study.

\section{Genotype determination}

Genomic DNA was isolated from blood cells using Phenol-Chloroform extraction method. Genotypic analysis of the XRCC1 $399 \mathrm{G}>$ A polymorphism was determined by the PCR-based restriction fragment length polymorphism (PCR-RFLP) method, as described in detail earlier [28]. Briefly, PCR primers for the XRCC1 codon 194 (forward 5'-GCCCCGTCCCAGGTA-3' and reverse 5'-AGCCCCAAGACCCTTTCATC-3') were used to generate a 292 bp product containing the polymorphic sites. PCR primers for the XRCC1 codon 399 (forward 5'-TTGTGCTTTCTCTGTGTCCA-3' and reverse 5'-TCCTCCAGCCTTTTCTGATA$3^{\prime}$ ) were used to generate a $615 \mathrm{bp}$ product containing the polymorphic sites. The PCR was carried out in a MJ Research, INC thermal cycler, model PTC-100 (Waltham, MA, USA). The PCR reactions were carried out in a $20 \mu \mathrm{l}$ 
volume of 20 pmol of each primer, $0.2 \mathrm{mM}$ each dNTP and $1 \mu \mathrm{l}$ buffer and $1 \mathrm{U}$ of Taq polymerase, with a denaturation of $94^{\circ} \mathrm{C}$ for $5 \mathrm{~min}$, followed by 30 cycles of $30 \mathrm{~s}$ at $61^{\circ} \mathrm{C}$ and $45 \mathrm{~s}$ at $72^{\circ} \mathrm{C}$ and finally $7 \mathrm{~min}$ at $72^{\circ} \mathrm{C}$. Following amplification, PCR products were digested using $10 \mathrm{U}$ of restriction enzyme MspI (New England BioLabs, Beverly, MA, USA) for $16 \mathrm{~h}$ at $37^{\circ} \mathrm{C}$, and electrophoresed on a $3 \%$ agarose gel. The wild type Arg allele for codon 194 is determined by the presence of a band at 292 bp, while the mutant Trp allele is determined by the presence of a band at $313 \mathrm{bp}$ (indicative of the absence of the MspI cutting site). In addition to these bands, a 174 bp band, resulting from an additional invariant cutting site for MspI in the 491 bp amplified fragment (codon 194) is always present and serves as internal control for complete MspI digestion. The wild type Arg allele for codon 399 is determined by the presence of two bands at 374 and $221 \mathrm{bp}$, while the mutant Gln allele is determined by the presence of the uncut $615 \mathrm{bp}$ band (indicative of the absence of the MspI cutting site).

\section{Data analysis}

The allelic frequencies were estimated by gene counting and genotypes were scored. The $\chi^{2}$ test was used to compare the observed numbers of genotypes with those expected for a population in the Hardy-Weinberg equilibrium and to test the significance of the differences of observed alleles and genotypes between groups. The odds ratios (ORs) and 95\% confidence intervals (CIs) were calculated by using a logistic regression model. The t-test (for normal distribution) or Manne-Whitney test (for nonnormal distribution) was used to compare each parameter between two groups (i.e. sex and age). An analysis of variance test was used to identify parameters that would make significant differences between more than two groups; Scheffe's test was then used to assess the significance of difference in each identified parameter between any two groups. STATISTICA 6.0 software (Statsoft, Tulsa, OK, USA) was used to perform analyses.

\section{Results and discussion}

In this work we investigated two common single nucleotide polymorphisms of XRCC1 gene Arg194Trp and
Arg399Gln and their association with human head and neck squamous cell carcinoma. The genotype analysis of these two SNPs of XRCC1 gene, for 92 HNSCC patients and 124 controls of cancer free subjects, in Polish population were performed using PCR-RFLP method. The polymorphisms chosen for this study have been shown to have functional significance and may be responsible for a low DNA repair capacity phenotype characteristic of cancer patients including head and neck squamous carcinomas [29-32]. The characteristic of HNSCC patens group according to age, sex, tumor stage and smoking status data was displayed in table 1.

Genome integrity is maintained by an intricate network of DNA repair proteins [33,34]. Organisms have developed several DNA-repair pathways as well as DNA-damage checkpoints. Defects in this complex machinery are associated with genotoxic susceptibility and familial predispositions to cancer [35]. Increasing evidence links environmental exposures, subtle modification in DNA repair efficiency, and cancer risk [36]. XRCC1 participates in DNA single strand break and base excision repair to protect genome stability in mammalian cells. One of the common polymorphisms of XRCC1 the Arg399Gln is located in the BRCT1 domain responsible for interacting with other repair components of BER. It was reported that Arg $\rightarrow$ Gln substitution produces significant conformational changes at BRCT1 domain that may be critical for DNA repair protein-protein interactions [37], thus absence or impairment repair may cause genome instability and cancer occurrence. It is also important to integrate DNA-repair process with DNA-damage checkpoints and cell survival, to evaluate the role of DNA repair at both cellular and organismic levels. Therefore, protective effects of XRCC1 polymorphisms in cancer may also be observed by the enhanced efficiency of apoptosis at a cellular level as a result of diminished DNA repair capacity secondary to the genetic polymorphisms [38,39].

In our study, neither of these SNPs was found to individually contribute to head and neck cancer risk. There were no differences between the distribution of the genotypes or alleles frequences in patients and controls. However,

Table I: The characteristic of patients group with squamous cell carcinoma of the head and neck (HNSCC).

\begin{tabular}{|c|c|c|c|c|c|c|c|c|c|c|c|c|c|c|c|c|}
\hline \multirow{3}{*}{$\begin{array}{c}\text { Patients } \\
\text { No. }\end{array}$} & \multirow{3}{*}{\multicolumn{2}{|c|}{$\begin{array}{l}\text { Sex } \\
\text { women }\end{array}$}} & \multicolumn{10}{|c|}{$\begin{array}{l}\text { Tumor stage } \\
\text { (TNM) }\end{array}$} & \multicolumn{4}{|c|}{$\begin{array}{c}\text { Smoking status } \\
\text { (cigarettes per day) }\end{array}$} \\
\hline & & & \multicolumn{4}{|c|}{$\mathrm{T}$} & \multicolumn{4}{|c|}{$N$} & \multicolumn{2}{|c|}{$M$} & \multirow[t]{2}{*}{ non } & \multirow[t]{2}{*}{$10 c c^{*}$} & \multirow[t]{2}{*}{$20 \mathrm{cc} *$} & \multirow[t]{2}{*}{$20 \mathrm{cc} * * * *$} \\
\hline & & & 1 & 2 & 3 & 4 & 0 & 1 & 2 & 3 & 0 & 1 & & & & \\
\hline 92 & 83 & 9 & 15 & 17 & 31 & 29 & 62 & 15 & 10 & 5 & 92 & 0 & 26 & 9 & 33 & 24 \\
\hline
\end{tabular}

$\mathrm{T}(\mathrm{I}-4)$ - size or direct extent of the primary tumor; $\mathrm{N}(0-3)$ - degree of spread to regional lymph nodes; $\mathrm{M}(0 / \mathrm{I})$ - presence of metastasis; non not smoking; * - smoking for ten years; ** - smoking for twenty years; *** - smoking for thirty years. 
we found statistically non-significant increase of Arg194Trp genotype frequency (OR, 1.37; 95\% CI, 0.702.68) and $\operatorname{Trp}^{194}$ allele (OR, 1.32; 95\% CI, 0.70-2.49) according to wild-type of Arg194Arg reference genotype and Arg194 allele frequency (table 2). Non-statistical increase of Arg399Gln (OR, 1.10; 95\% CI, 0.61-1.97) according to reference genotype of Arg399Arg was also found. (table 3). While, no altered risk has been found individually for the XRCC1 Arg194Trp or Arg399Gln polymorphisms, the halophyte analysis according to wildtype of Arg194Arg-Arg399Arg showed high association with head and neck cancer (table 4 ). The findings indicated that a statistically non-significantly increased risk of HNSCC was associated with the combined Arg194ArgArg399Gln genotype (OR, 1.33; 95\% CI, 0.70-2.56). The higher risk of head and neck cancer occurrence was associated with the combined Arg194Trp-Arg399Arg genotype (OR, 2.96; 95\% CI, 1.01-8.80) but no altered risk was associated with others haplotypes. For Tyr165Tyr genotype we also observed positive correlation with cancer progression assessed by tumor size (OR 4.56; 95\% CI 1.60-12.95).

We also analyzed the distribution of genotypes and frequency of alleles in groups of patients suffer head and neck cancer according to different cancer staging by TNM classification (table 5 and table 6). We did not find any association of the Arg194Tyr or Arg399Gln polymorphisms in patients group with cancer progression assessed by with tumour size $(\mathrm{T})$ and node status $(\mathrm{N})$. Additionally, as a high risk factor for head and neck cancer occurrence we analysed patients with positive smoking status within HNSCC group according to smokers selected from controls (table 7 and table 8). While, no statistically significant differences in distribution of the Arg194Tyr genotype was calculated, we found statistically significant associations of Arg399Gln polymorphic variants of XRCC1 gene with cancer risk within smoking group of HNSCC patients. We found that Arg399Gln genotype frequency (OR, 2.70; 95\% CI, 1.26-5.78) and Gln399 allele (OR, 4.31; 95\% CI, 2.29-8.13) was associated with patients group smoked ten or more cigarettes per day for at least ten years. On the other hand Arg399Arg wild-type genotype (OR, 0.18; 95\% CI, 0.08-0.39) and Arg399 allele (OR, 0.22; 95\% CI, 0.12-0.41) had protective effect on cancer risk even in patients group with positive smoking status.

The XRCC1 gene polymorphisms have been extensively studied in the association with various human cancers mostly breast, lung or head and neck carcinomas. Major studies of head and neck cancer has been focused on polymorphisms of genes encoding enzymes of xenobiotic metabolism and DNA repair [32,40]. Carriers of the XRCC1 Arg399Gln variant have been shown to have higher levels of DNA adducts [16] and to be at greater risk for ionizing radiation sensitivity [17] and tobacco correlated DNA damage [18-20]. Recently, Sreeja at al (2008) has shown that the carriers of XRCC1 Gln399Gln genotypes were at higher risk of lung cancer [12]. On the other hand, López-Cima et al. (2007) has been reported that individuals homozygous for the XRCC1 Gln339 allele presented no risk of developing lung cancer [6]. The association between XRCC1 Arg399Gln polymorphism and ductal carcinoma of women with breast cancer was found statistically significant in studies performed by Dufloth et al. at 2008 [13]. Despite of large number of studies, in well-characterized populations, results from HNSCC patients are still confusing. There was a marginally significant risk of HNSCC observed in variants of XRCC1 genotype with Trp194 allele in Thailand population [41]. No altered risk was associated with the XRCC1 Arg399Gln genotype in Li et al. studies [42], however smokers carrying risk genotype of XRCC1 with dominant Gln399 allele were over-represented in head and neck cancer populations from eastern region of India [43]. Recently, combinational polymorphisms of four DNA repair genes XRCC1, XRCC2, XRCC3, and XRCC4 and their association with HNSCC cancer in Taiwan has been investigated. [14]. Except for XRCC2, none of SNPs was found to individually contribute to cancer risk. In our study, we found that Gln399 allele may also increase head and neck cancer risk in population with positive smoking status. Finally, no association was found individually for either analyzed SNPs but we evidenced that combined genotypes of XRCC1 may have impact on HNSCC risk.

Table 2: Distribution of genotypes and frequency of alleles of the Arg/Trp 194 (C/T 26304 exon 6) polymorphism of XRCCI gene in squamous cell carcinoma of the head and neck (HNSCC) patients and the controls.

\begin{tabular}{|c|c|c|c|}
\hline Genotype Allele & $\begin{array}{c}\text { HNSCC patients } \\
(\mathrm{n}=92) \\
\text { Number (frequency) }\end{array}$ & $\begin{array}{c}\text { Controls } \\
(\mathrm{n}=124)\end{array}$ & OR (95\% CI) \\
\hline Arg/Arg & $71(0.86)$ & $102(0.82)$ & I (reference) \\
\hline Arg/Trp & $21(0.14)$ & $22(0.18)$ & $1.37(0.70 ; 2.68)$ \\
\hline Trp/Trp & $0(0.00)$ & $0(0.00)$ & ------ \\
\hline Arg & $163(0.98)$ & $226(0.91)$ & I (reference) \\
\hline Trp & $21(0.12)$ & $22(0.09)$ & I.32 $(0.70 ; 2.49)$ \\
\hline
\end{tabular}


Table 3: Distribution of genotypes and frequency of alleles of the Arg/GIn 399 (G/A 28 I 52 exon 9) polymorphism of XRCCI gene in squamous cell carcinoma of the head and neck (HNSCC) patients and the controls.

\begin{tabular}{|c|c|c|c|}
\hline Genotype Allele & $\begin{array}{c}\text { HNSCC patients } \\
(\mathrm{n}=92) \\
\text { Number (frequency) }\end{array}$ & $\begin{array}{c}\text { Controls } \\
(n=124)\end{array}$ & OR $(95 \% \mathrm{Cl})$ \\
\hline Arg/Arg & $37(0,40)$ & $49(0.40)$ & I (reference) \\
\hline Arg/Gln & $44(0.48)$ & $53(0.43)$ & $1.10(0.61 ; 1.97)$ \\
\hline $\mathrm{G} \ln / \mathrm{Gln}$ & $11(0.12)$ & $22(0.18)$ & $0.66(0.29 ; 1.53)$ \\
\hline Arg & $118(0.64)$ & $151(0.61)$ & I (reference) \\
\hline Gln & $66(0.36)$ & $97(0.39)$ & $0.87(0.59 ; 1.29)$ \\
\hline
\end{tabular}

Table 4: Haplotypes distribution and frequencies of $X R C C I$ gene polymorphisms in squamous cell carcinoma of the head and neck (HNSCC) patients and the controls.

\begin{tabular}{|c|c|c|c|}
\hline Haplotypes XRCCI-194-399 & $\begin{array}{c}\text { HNSCC patients } \\
(\mathrm{n}=92) \\
\text { Number (frequency) }\end{array}$ & $\begin{array}{c}\text { Controls } \\
(n=\mid 24)\end{array}$ & OR $(95 \% \mathrm{Cl})$ \\
\hline Arg/Arg-Arg/Arg & $29(0,32)$ & $43(0,35)$ & I (reference) \\
\hline Arg/Trp-Arg/Arg & $12(0.13)$ & $6(0.05)$ & $2.96(1.01 ; 8.80)$ \\
\hline Trp/Trp-Arg/Arg & $0(0.00)$ & $0(0.00)$ & ------ \\
\hline Arg/Arg-Arg/Gln & $36(0.39)$ & $40(0.32)$ & $1.33(0.70 ; 2.56)$ \\
\hline Arg/Trp-Arg/Gln & $8(0,09)$ & $13(0,10)$ & $0.91(0.34 ; 2.48)$ \\
\hline Trp/Trp-Arg/Gln & $0(0.00)$ & $0(0.00)$ & ------ \\
\hline Arg/Arg-Gln/Gln & $6(0.07)$ & $19(0.15)$ & $0.47(0.17 ; 1.31)$ \\
\hline Arg/Trp-Gln/Gln & $\mathrm{I}(0.01)$ & $3(0.02)$ & $0.49(0.05 ; 4.99)$ \\
\hline Trp/Trp-Gln/Gln & $0(0,00)$ & $0(0,00)$ & ------- \\
\hline
\end{tabular}

Table 5: The genotype and allele frequency and odds ratios (OR) of the Arg 194Trp polymorphism of XRCCI gene in patients with head and neck cancer with different tumor size and lymph node status.

\begin{tabular}{|c|c|c|c|c|c|c|}
\hline \multirow[b]{2}{*}{ Genotype Allele } & \multicolumn{3}{|c|}{ Tumour size (T) } & \multicolumn{3}{|c|}{ Node status (N) } \\
\hline & $\begin{array}{c}\mathrm{T} 3+\mathrm{T} 4 \\
\text { Number/Frequency }\end{array}$ & $\begin{array}{c}\text { T1+ T2 } \\
\text { Number/Frequency }\end{array}$ & OR $(95 \% \mathrm{Cl})$ & $\begin{array}{c}\mathrm{N} 1+\mathrm{N} 2+\mathrm{N} 3 \\
\text { Number/Frequency }\end{array}$ & $\begin{array}{c}\text { No } \\
\text { Number/Frequency }\end{array}$ & OR $(95 \% \mathrm{Cl})$ \\
\hline Arg/Arg & $43(0.72)$ & $28(0.88)$ & $0.36(0.1 I-I .19)$ & $20(0.67)$ & $5 \mathrm{I}(0.82)$ & $0.43(0.16-1.67)$ \\
\hline Arg/Trp & $17(0.28)$ & $4(0.12)$ & $2.76(0.84-9.08)$ & $10(0.33)$ & II (0.18) & $2.32(0.85-6.30)$ \\
\hline Trp/Trp & $0(0.00)$ & $0(0.00)$ & -------- & $0(0.00)$ & $0(0.00)$ & ------ \\
\hline Arg & $103(0.86)$ & $60(0.96)$ & $0.40(0.13-1.27)$ & $50(0.83)$ & $113(0.91)$ & $0.48(0.19-1.32)$ \\
\hline Trp & $17(0.14)$ & $4(0.14)$ & $2.47(0.80-7.70)$ & $10(0.17)$ & II (0.09) & $2.05(0.82-5.14)$ \\
\hline
\end{tabular}

Table 6: The genotype and allele frequency and odds ratios (OR) of the Arg399GIn polymorphism of XRCCI gene in patients with head and neck cancer with different tumor size and lymph node status.

\begin{tabular}{|c|c|c|c|c|c|c|}
\hline \multirow[b]{2}{*}{ Genotype Allele } & \multicolumn{3}{|c|}{ Tumour size (T) } & \multicolumn{3}{|c|}{ Node status (N) } \\
\hline & $\begin{array}{c}\text { T3 }+ \text { T4 } \\
\text { Number/Frequency }\end{array}$ & $\begin{array}{c}\text { TI+ T2 } \\
\text { Number/Frequency }\end{array}$ & OR $(95 \% \mathrm{Cl})$ & $\begin{array}{c}\mathrm{N} 1+\mathrm{N} 2+\mathrm{N} 3 \\
\text { Number/Frequency }\end{array}$ & $\begin{array}{c}\text { No } \\
\text { Number/Frequency }\end{array}$ & OR $(95 \% \mathrm{Cl})$ \\
\hline Arg/Arg & $24(0.40)$ & $13(0.4 I)$ & $0,97(0.4 I-2.34)$ & $8(0,27)$ & $29(0.47)$ & $0.4 I(0.16-1.07)$ \\
\hline Arg/Gln & $30(0.50)$ & $14(0.44)$ & $1.28(0.54-3.05)$ & $17(0.57)$ & $27(0.44)$ & $1.70(0.70-4.08)$ \\
\hline $\mathrm{G} \ln / \mathrm{G} \ln$ & $6(0.10)$ & $5(0.16)$ & $0.60(0.17-2.14)$ & $5(0.17)$ & $6(0.10)$ & $1.86(0.52-6.70)$ \\
\hline Arg & $78(0.65)$ & $40(0.62)$ & I.II $(0.59-2.09)$ & $33(0.55)$ & $85(0.69)$ & $0.56(0.30-1.06)$ \\
\hline Gln & $42(0.35)$ & $24(0.38)$ & $0.89(0.48-1.68)$ & $27(0.45)$ & $39(0.31)$ & $1.78(0.94-3.36)$ \\
\hline
\end{tabular}


Table 7: The genotype and allele frequency and odds ratios (OR) of the Arg 194Trp polymorphism of XRCCI gene in squamous cell carcinoma of the head and neck (HNSCC) patients and the controls with positive smoking status.

\begin{tabular}{|c|c|c|c|}
\hline Genotype Allele & $\begin{array}{c}\text { HNSCC patients } \\
(n=66) \\
\text { Number (frequency) }\end{array}$ & $\begin{array}{c}\text { Controls } \\
(\mathrm{n}=52) \\
\text { Number (frequency) }\end{array}$ & OR $(95 \% \mathrm{Cl})$ \\
\hline Arg/Arg & $49(0.74)$ & $44(0.85)$ & $0.52(0.20-1.33)$ \\
\hline Arg/Trp & $17(0.26)$ & $8(0.15)$ & $1.91(0.75-4.85)$ \\
\hline Trp/Trp & $0(0.00)$ & $0(0.00)$ & ------- \\
\hline Arg & $115(0.87)$ & $96(0.92)$ & $0.56(0.23-1.36)$ \\
\hline Trp & $17(0.13)$ & $8(0.08)$ & $1.77(0.73-4.28)$ \\
\hline
\end{tabular}

Table 8: The genotype and allele frequency and odds ratios (OR) of the Arg399GIn polymorphism of XRCCI gene in squamous cell carcinoma of the head and neck (HNSCC) patients and the controls with positive smoking status.

\begin{tabular}{|c|c|c|c|}
\hline Genotype Allele & $\begin{array}{c}\text { HNSCC patients } \\
(\mathrm{n}=66) \\
\text { Number (frequency) }\end{array}$ & $\begin{array}{c}\text { Controls } \\
(\mathrm{n}=52) \\
\text { Number (frequency) }\end{array}$ & OR $(95 \% \mathrm{Cl})$ \\
\hline Arg/Arg & $19(0.29)$ & $36(0.69)$ & $0.18(0.08-0.39)$ \\
\hline Arg/Gln & $36(0.55)$ & $16(0.31)$ & $2.70(1.26-5.78)$ \\
\hline$G \ln / G \ln$ & II (0.16) & $0(0.00)$ & ------- \\
\hline Arg & $74(0.56)$ & $88(0.85)$ & $0.22(0.12-0.4 I)$ \\
\hline Gln & $58(0.44)$ & $16(0.15)$ & $4.31(2.29-8.13)$ \\
\hline
\end{tabular}

\section{Conclusion}

Head and neck cancer patients have variable prognoses even within the same clinical stage and while receiving similar treatments. The number of studies of genetic polymorphisms as prognostic factors of HNSCC outcomes is growing. Candidate polymorphisms have been evaluated in DNA repair, cell cycle, xenobiotic metabolism, and growth factor pathways. In our study, we assessed two common polymorphisms of the XRCC1 gene that might influence DNA repair capacity and their association with head and neck cancer risk. Finally, we identified the combined genotype of Arg194Trp-Arg399Arg that was associated with HNSCC cancer risk and may have an impact on identification of a high-risk population.

\section{Competing interests}

The authors declare that they have no competing interests.

\section{Authors' contributions}

MK have made substantial contributions to conception, design and drafting the manuscript. KP, PR, WP, AB-K and JS have made acquisition of data, analysis and interpretation of data. WM, JO, AM-S have made substantial contributions to patients sample collection. IM has made substantial contributions to conception and design, acquisition of data, analysis and interpretation of data, drafting the manuscript and revising it critically for important intellectual content. He has also given final approval of the version to be published.

\section{Acknowledgements}

This work was supported by grant N30I 099 32/358I from Polish Ministry of Science and Higher Education.

\section{References}

I. Lindahl T, Wood RD: Quality control by DNA repair. Science 1999, 286:1897-1905.

2. Hoeijmakers JH: Genome maintenance mechanisms for preventing cancer. Nature 200 I, 4I I:366-374.

3. Barnes $D E$, Lindahl $T$ : Repair and genetic consequences of endogenous DNA base damage in mammalian cells. Annu Rev Genet 2004, 38:445-476.

4. Vogelstein B, Kinzler KW: Cancer genes and the pathways they control. Nat Med 2004, 10:789-799.

5. Mohrenweiser HW, Wilson DM III, Jones IM: Challenges and complexities in estimating both the functional impact and the disease risk associated with the extensive genetic variation in human DNA repair genes. Mutat Res 2003, 526:93- 125.

6. López-Cima MF, González-Arriaga P, García-Castro L, Pascual T, Marrón MG, Puente XS, Tardón A: Polymorphisms in XPC, $X P D, X R C C I$, and $X R C C 3$ DNA repair genes and lung cancer risk in a population of northern Spain. BMC Cancer 2007, 7:162.

7. Martinez-Balibrea E, Manzano JL, Martinez-Cardus A, Moran T, Cirauqui $B$, Catot $S$, Taron M, Abad A: Combined analysis of genetic polymorphisms in thymidylate synthase, uridine diphosphate glucoronosyltransferase and $X$-ray cross complementing factor I genes as a prognostic factor in advanced colorectal cancer patients treated with 5-fluorouracil plus oxaliplatin or irinotecan. Oncol Rep 2007, 17(3):637-645.

8. Burri RJ, Stock RG, Cesaretti JA, Atencio DP, Peters S, Peters CA, Fan G, Stone NN, Ostrer H, Rosenstein BS: Association of single nucleotide polymorphisms in SOD2, XRCCI and XRCC3 with susceptibility for the development of adverse effects resulting from radiotherapy for prostate cancer. Radiat Res 2008, 170 (I):49-59.

9. McWilliams RR, Bamlet WR, Cunningham JM, Goode EL, de Andrade $M$, Boardman LA, Petersen GM: Polymorphisms in DNA repair genes, smoking, and pancreatic adenocarcinoma risk. Cancer Res 2008, I 5;68(12):4928-4935. 
10. Fontana L, Bosviel R, Delort L, Guy L, Chalabi N, Kwiatkowski F, Satih S, Rabiau N, Boiteux JP, Chamoux A, Bignon YJ, Bernard-Gallon DJ: DNA repair gene ERCC2, XPC, XRCCI, XRCC3 polymorphisms and associations with bladder cancer risk in a French cohort. Anticancer Res 2008, 28(3B): I853-1856.

II. Wang Z, Xu B, Lin D, Tan W, Leaw S, Hong X, Hu X: XRCCI polymorphisms and severe toxicity in lung cancer patients treated with cisplatin-based chemotherapy in Chinese population. Lung Cancer 2008, 62(I):99-104.

12. Sreeja L, Syamala VS, Syamala V, Hariharan S, Raveendran PB, Vijayalekshmi RV, Madhavan J, Ankathil R: Prognostic importance of DNA repair gene polymorphisms of XRCCI Arg399GIn and XPD Lys75 I GIn in lung cancer patients from India. J Cancer Res Clin Oncol 2008, I34(6):645-652.

13. Dufloth RM, Arruda A, Heinrich JK, Schmitt F, Zeferino LC: The investigation of DNA repair polymorphisms with histopathological characteristics and hormone receptors in a group of Brazilian women with breast cancer. Genet Mol Res 2008, 1;7(3):574-582.

14. Yen CY, Liu SY, Chen $\mathrm{CH}$, Tseng HF, Chuang LY, Yang CH, Lin YC, Wen $\mathrm{CH}$, Chiang WF, Ho CH, Chen HC, Wang ST, Lin CW, Chang HW: Combinational polymorphisms of four DNA repair genes XRCCI, XRCC2, XRCC3, and XRCC4 and their association with oral cancer in Taiwan. J Oral Pathol Med 2008, 37(5):27I-277.

15. Shall S, de Murcia G: Poly(ADP-ribose) polymerase-I: what have we learned from the deficient mouse model? Mutat Res 2000, 460: I- I5.

16. Lunn RM, Langlois RG, Hsieh LL, Thompson CL, Bell DA: XRCCI polymorphisms: effects on aflatoxin $B I-D N A$ adducts and glycophorin A variant frequency. Cancer Res 1999, 59:2557-2561.

17. Hu JJ, Smith TR, Miller MS: Amino acid substitution variants of APEI and $X R C C I$ genes associated with ionizing radiation sensitivity. Carcinogenesis 200I, 22:917-922.

18. Duell EJ, Wiencke JK, Cheng TJ, Varkonyi A, Zuo ZF, Ashok TD, Mark EJ, Wain JC, Christiani DC, Kelsey KT: Polymorphisms in the DNA repair genes $X R C C I$ and ERCC2 and biomarkers of DNA damage in human blood mononuclear cells. Carcinogenesis 2000, 21:965-971.

19. Abdel-Rahman SZ, El Zein RA: The 399GIn polymorphism in the DNA repair gene $X R C C I$ modulates the genotoxic response induced in human lymphocytes by the tobacco-specific nitrosamine NNK. Cancer Lett 2000, 159:63-71.

20. Lei YC, Hwang SJ, Chang CC, Kuo HW, Luo JC, Chang MJ, Cheng TJ: Effects on sister chromatid exchange frequency of polymorphisms in DNA repair gene $X R C C I$ in smokers. Mutat Res 2002, 519:93-101.

21. Kubota Y, Nash RA, Klungland A, Schar P, Barnes DE, Lindahl T: Reconstitution of DNA base excision-repair with purified human proteins: interaction between DNA polymerase beta and the XRCCI protein. EMBO J 1996, I5:6662-6670.

22. Caldecott $\mathrm{KW}: X R C C I$ and DNA strand break repair. DNA Repair 2003, 2:955-969.

23. Marsin S, Vidal AE, Sossou M, Ménissier-de Murcia J, Le Page F, Boiteux S, de Murcia G, Radicella JP: Role of XRCCI in the coordination and stimulation of oxidative DNA damage repair initiated by the DNA glycosylase hOGGI. J Biol Chem 2003 , 278(45):44068-74.

24. Campalans A, Marsin S, Nakabeppu Y, O'connor TR, Boiteux S, Radicella JP: XRCCI interactions with multiple DNA glycosylases: a model for its recruitment to base excision repair. DNA Repair (Amst) 2005, 4(7):826-35.

25. Nazarkina ZK, Khodyreva SN, Marsin S, Lavrik OI, Radicella JP. $\mathrm{XRCCI}$ interactions with base excision repair DNA intermediates. DNA Repair (Amst) 2007, 6(2):254-64.

26. Koskinen W]: Prognostic markers in head and neck carcinoma. In Academic Dissertation Haartman Institute, Helsinki; 2006:21-27.

27. Zhou W, Liu G, Miller DP, Thurston SW, Li Lian X, Wain JC, Lynch T], Li S, Christiani DC: Gene-environment interaction for the ERCC2 polymorphisms and cumulative cigarette smoking exposure in lung cancer. Cancer Res 2002, 62:1377-I38I.

28. Stern MC, Siegmund KD, Corral R, Haile RW: XRCCI and XRCC3 Polymorphisms and Their Role as Effect Modifiers of Unsatu- rated Fatty Acids and Antioxidant Intake on Colorectal Adenomas Risk. Cancer Epidemiol Biomarkers Prev 2005, I4(3):609-6I5.

29. Helzlsouer KJ, Harris EL, Parshad R, Perry HR, Price FM, Sanford KK: DNA repair proficiency: potential susceptiblity factor for breast cancer. J Natl Cancer Inst 1996, 88:754-755.

30. Wei Q, Spitz MR: The role of DNA repair capacity in susceptibility to lung cancer: a review. Cancer Metastasis Rev 1997. 16:295-307.

31. Hopkins J, Cescon DW, Tse D, Bradbury P, Xu W, Ma C, WheatleyPrice P, Waldron J, Goldstein D, Meyer F, Bairati I, Liu G: Genetic polymorphisms and head and neck cancer outcomes: a review. Cancer Epidemiol Biomarkers Prev 2008, 17:490-499.

32. Hiyama T, Yoshihara M, Tanaka S, Chayama K: Genetic polymorphisms and head and neck cancer risk (Review). Int J Oncol 2008, 32:945-73.

33. Lindahl T: Keynote: past, present, and future aspects of base excision repair. Prog Nucleic Acid Res Mol Biol 200I, 68: 17-30.

34. Hoeijmakers JH: Genome maintenance mechanisms for preventing cancer. Nature 200I, 4 I I:366-374.

35. Bohr VA: DNA damage and its processing: relation to human disease. J Inherit Metab Dis 2002, 25:215-222.

36. Mohrenweiser HW, Wilson DM III, Jones IM: Challenges and complexities in estimating both the functional impact and the disease risk associated with the extensive genetic variation in human DNA repair genes. Mutat Res 2003, 526:93-125.

37. Monaco R, Rosal R, Dolan MA, Pincus MR, Brandt-Rauf PW: Conformational effects of a common codon 399 polymorphism on the BRCTI domain of the XRCCI protein. Protein J 2007, 26(8):54|-6.

38. Olshan AF, Watson MA, Weissler MC, Bell DA: XRCCI polymorphisms and head and neck cancer. Cancer Lett 2002, I78(2): $|8|-6$.

39. Nelson HH, Kelsey KT, Mott LA, Karagas MR: The XRCCI Arg399 Gln polymorphism, sunburn, and non-melanoma skin cancer: evidence of gene-environment interaction. Cancer Res 2002, 62(I): I52-5.

40. Harth V, Schafer M, Abel J, Maintz L, Neuhaus T, Besuden M, Primke R, Wilkesmann A, Thier R, Vetter H, Ko YD, Bruning T, Bolt HM, Ickstadt $K$ : Head and neck squamous-cell cancer and its association with polymorphic enzymes of xenobiotic metabolism and repair. J Toxicol Environ Health A 2008, 71:887-897.

41. Kietthubthew S, Sriplung H, Au WW, Ishida T: Polymorphism in DNA repair genes and oral squamous cell carcinoma in Thailand. Int J Hyg Environ Health 2006, 209(I):2I-29.

42. Li C, Hu Z, Lu J, Liu Z, Wang LE, El-Naggar AK, Sturgis EM, Spitz MR, Wei Q: Genetic polymorphisms in DNA base-excision repair genes ADPRT, XRCCI, and APEI and the risk of squamous cell carcinoma of the head and neck. Cancer 2007, I 5; I I 0(4):867-875

43. Majumder M, Sikdar N, Paul RR, Roy B: Increased risk of oral leukoplakia and cancer among mixed tobacco users carrying XRCCI variant haplotypes and cancer among smokers carrying two risk genotypes: one on each of two loci, GSTM3 and XRCCI (Codon 280). Cancer Epidemiol Biomarkers Prev 2005, I4(9):2106-2। I2

Publish with Bio Med Central and every scientist can read your work free of charge

"BioMed Central will be the most significant development for disseminating the results of biomedical research in our lifetime. "

Sir Paul Nurse, Cancer Research UK

Your research papers will be:

- available free of charge to the entire biomedical community

- peer reviewed and published immediately upon acceptance

- cited in PubMed and archived on PubMed Central

- yours - you keep the copyright 